AJIT-e: Online Academic Journal of Information Technology

2018- Informatics and Communication Technologies Special Issue/iletişim ve Bilişim Teknolojileri

Özel Sayı -Cilt/Vol: 9-Sayı/Num: 35

DOI: 10.5824/1309-1581.2018.5.001.x

http://www.ajit-e.org/?menu=pages\&p=details_of_article\&id=390

Received : 19.11 .2018

Editorial Process Begin: 03.12.2018

Published: 26.12.2018

\title{
Improving the Institutional Environment of the Innovation Economy in Azerbaijan
}

Ferhad P. RAHMANOV, Azerbaijan State University of Economics Baku/Azerbaijan, farhad52@live.ru

Elçin SULEYMANOV, Baku Engineering University Baku/Azerbaijan, elsuleymanov@beu.edu.az

Yahya ÖZDEMiR, Yalova University, Vocational School / Turkey, yahya.ozdemir56@gmail.com

\begin{abstract}
The author's model of the institutional environment of innovative economy is given, the innovation processes and infrastructure institutions at the current stage of formation of innovation economy of the Azerbaijan Republic are being analyzed, and the main problems in development of elements of the institutional environment are identified. Suggestions are related with the possible ways to improve the nstitutional environment of the innovation economy in Azerbaijan.
\end{abstract}

Keywords: Innovation economy, Institutional environment, National innovation system

\section{Azerbaycanda Teknolojik Altyapısı Oluşumunun İnnovasyona Dayalı Ekonominin Gelişimine Katkısı}

ÖZ

\begin{abstract}
Makalede Azerbaycan Cumhuriyeti'nin inovasyon ekonomisinin kurumsal yapısının oluşum süreci üzerine bir çalışma yapılmıştır, Ülkenin yenilikçi ekonomisinin oluşum aşamasında mevcut olan ınnovasyon kurumlarının ve altyapı kuruluşlarının durumunun analizine özel önem verilmiştir. Çalışmada Azerbaycan Cumhuriyetinın yenilikçi ekonomisinin kurumsal ortamdaki değişikliklerin hızının yetersizliklerinin nedenleri açıklanmakta, etkinliğini arttırmak için devletin düzenleyici ve koordinasyon rolünün güçlendirilmesinin gerekli olduğuna dikkat çekilmekte ve Azerbaycan'da inovasyon ekonomisinin güncel kurumsal ortamının iyileştirilmesi için öneriler verilmiştir.
\end{abstract}

Anahtar Kelimeler: Innovasyona dayalı ekonomi, Kurumsal çevre, Ulusal inovasyon sistemi

\section{INTRODUCTION}

At the present stage of society development only a transition to an innovative path of development could ensure the sustainable economic growth and the country's competitiveness in the global economy. The innovative development of the Azerbaijan economy has not yet acquired a dynamic character and it is difficult to highlight any 


\section{AJIT-e: Online Academic Journal of Information Technology \\ December 2018 - Special Issue/Aralık 2018 Özel Sayısı -Cilt/Vol: 9-Sayı/Num: 35 \\ DOI: 10.5824/1309-1581.2018.5.001.x}

established patterns inherent in this process. The formation of a national innovation system remains a slow and contradictory process. This predetermines the need to develop a mechanism and measures to improve the government actions in the formation of an innovation system, its institutional foundations in Azerbaijan.

For a long time, the problems of forming the innovative economy are at the spotlight of numerous studies (ANAS News, 2011; Alguliev R. et al., 2013; Blyakhman L.S. et al., 2011; Karova E.A., 2010; Sklyarova E.E., 2012; Lengrand L., 2008).

The works devoted to the study of the issues determining the state regulation mechanism of innovative development and assessing the role of the state in this process are of great importance for the studied problem (Eroshin A., 2011; Shepelev G.V.).

In general, an analysis of economic literature suggests that, despite the sufficient development of practical issues related to the problems of innovative economy development, at the current stage, there is a need for additional research on the development of the innovation sphere, rethinking government efforts to create an appropriate infrastructure and institutional environment appropriate to the situation.

This determines the importance of special studies of the institutional environment of the innovation economy, the factors of its formation and development in order to create a more holistic view of this phenomenon in Azerbaijan.

The purpose of this article is to study the institutional environment of the innovation economy and develop recommendations for improving the efficiency of the innovation policy mechanisms of the Azerbaijan Republic.

The article substantiates the conclusion that the modernization of the institutional environment should become an integral part of the development of the Azerbaijani economic system and be directed to resolve such problems as: restoration of the industrial base, overcoming the raw material imbalances in the sectoral structure of the national economy, transferring the economy to an innovative way of technological improvement.

As known, the national innovation system (NIS) is a complex of legal, financial and social institutions that provide innovation processes and have strong national and cultural characteristics (Ivanova N., 2011). The article notes that NIS is an institutional environment, the composition of elements and the features of the structural links between them determine the nature of the innovation economy and the model of innovation development of the economic system. From this position, the NIS should be understood as a set of institutions located at all stages of the innovation process, and infrastructure institutions linking these stages together in a single aggregate. The expediency of these institutions is justified by the range of specific functional tasks performed by them (Lenchuk E.B, et al., 2012).

The article substantiates the proposition that the institutional environment of an innovative economy should be created by the state, which also acts as a regulator and coordinator of its functioning. In the process of creating and regulating the institutional environment of an 
innovative economy, the following tasks are being solved at the macro level: NIS is formed, a favorable innovative climate is being created, an innovative strategy of the country is being developed and implemented.

The state acts as a regulatory and governing body and seeks to develop and implement socio-economic policies, whose main task is to create necessary conditions and encourage corporations to make long-term investments in innovation and the formation of social responsibility of business (Entrepreneurship in Azerbaijan, 2004; Aras O.N., et al., 2016; Aleksandrin Yu.N. , 2011; Kihlgren A. 2003).

Analysis of the dynamics of the institutional environment of the innovation economy in Azerbaijan revealed the problems that exist in its structural links. The analysis carried out in the article showed that the formation of an integrated institutional environment of the innovation economy is a primary task, its solution will speed up the transition of the Azerbaijani economy to the innovation path of development, will determine the continuity of the innovation process and increase its efficiency.

\section{Institutional Support for İnnovative Activity in Azerbaijan}

At present, the model of innovation infrastructure in the form of a complex of institutions of the Azerbaijan republic can be represented in Figure 1.

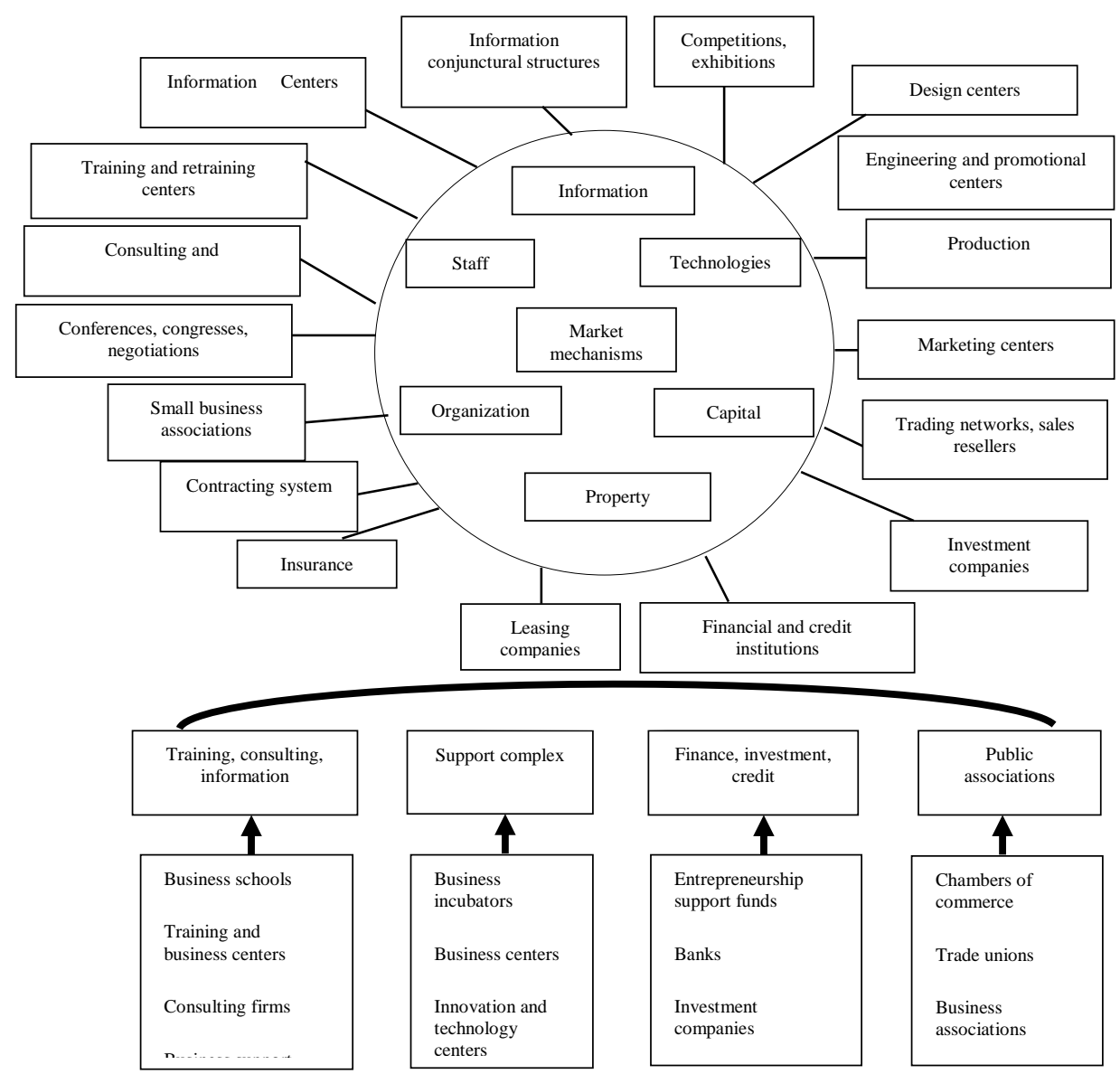

Figure 1. Institutional model of infrastructure support of the innovation economy 
Elements of infrastructure and institutional support for innovation have been created and function in Azerbaijan. However, there is no consistency in providing this support.

In particular, the institutions for the motivation of innovation activity remains underdeveloped, the innovative activity of domestic organizations is low to date as evidenced by the data of the State Statistics Committee of the Azerbaijan Republic.

In general, the volume of innovative products for 2005-2016 increased about 4.2 times and amounted to 35,747 thousand manat (Table 1).

With this, organizations of the service sector make a greater contribution to the creation of innovative products than industrial enterprises. This is due, in our opinion, lower costs for their creation, compared to technological innovations that are most in demand in industry.

Table 1. The volume of innovative products introduced for the first time by industry sectors, thousand manat

\begin{tabular}{|l|c|c|c|c|c|}
\hline \multirow{2}{*}{} & \multicolumn{5}{|c|}{ Products that have undergone major improvements and } \\
& \multicolumn{5}{|c|}{ products first introduced } \\
\cline { 2 - 6 } & 2005 & 2007 & 2011 & 2015 & 2016 \\
\hline Industry - total & 8531.0 & 826.2 & 13163.0 & 929.7 & 35747.0 \\
\hline Mining industry & - & 208.5 & 2073.0 & - & 129.6 \\
\hline Processing industry & 8531.0 & 617.7 & 11090.0 & 929.7 & 35617.0 \\
\hline including: & & & & & \\
\hline Chemical industry & 5915.0 & & - & 13.4 & 522.4 \\
\hline $\begin{array}{l}\text { Manufacture of machinery and } \\
\text { mechanisms }\end{array}$ & 95.6 & 355.3 & & 158.3 & 174.9 \\
\hline $\begin{array}{l}\text { Metallurgy and production of } \\
\text { finished products }\end{array}$ & - & & - & - & 9613.0 \\
\hline $\begin{array}{l}\text { Electrical equipment, optoelectronic } \\
\text { equipment }\end{array}$ & - & 262.4 & 13.5 & 738.5 & - \\
\hline
\end{tabular}

Source: State Statistical Committee of Azerbaijan Republic

The volume of expenses of organizations and enterprises for technological innovations in the Azerbaijan industry in dynamics is given in Table 2.

The analysis shows that if at the beginning of the analyzed period in 2005, most of the expenses on technological innovation were carried out in the field of fuel and energy minerals extraction ( $82.4 \%$ of the total amount of expenses), now production of machinery and equipment $(45.1 \%)$ is on the first place. For other types of economic activity, this share does not exceed $8 \%$

Table 2. Expenses on technological innovations in the Azerbaijani industry by type of economic activity, thousand manat 


\begin{tabular}{|l|c|c|c|c|c|}
\hline Expenses components & $\mathbf{2 0 0 4}$ & $\mathbf{2 0 0 5}$ & $\mathbf{2 0 1 0}$ & $\mathbf{2 0 1 5}$ & $\mathbf{2 0 1 6}$ \\
\hline Total industry a development of new & 131.2 & 853.5 & 2551.0 & 13283.0 & 5655.0 \\
\hline $\begin{array}{l}\text { Research and } \\
\text { products, processes and services }\end{array}$ & 39.4 & 1840.0 & 5053.0 & 12765.0 & 1963.0 \\
\hline $\begin{array}{l}\text { Purchase of machines and devices due to } \\
\text { technological innovations }\end{array}$ & 121.8 & 50573.0 & - & 3022.0 & 15919.0 \\
\hline New technologies procurement & - & - & - & 859.5 & 1217.0 \\
\hline Software procurement & - & - & 95.6 & 37.2 & 43.2 \\
\hline Personnel training for innovation & 53.4 & 4.6 & 300.1 & 5202.0 & 2700.0 \\
\hline $\begin{array}{l}\text { Production design, use new methods and } \\
\text { services for production }\end{array}$ & - & 0.82 & - & - & - \\
\hline Marketing research & 70.8 & 2.02 & 140.0 & - & - \\
\hline Technological innovation & & & & \\
\hline
\end{tabular}

Source: State Statistical Committee of Azerbaijan Republic

Recently, there has been a certain shift in the formation of an institutions for the support of ideas in the field of innovation.

The High-Tech Parks functioning in Azerbaijan were organized on the basis of Azerbaijan 2020 Development Concept ("Azerbaijan -2020", 2012).

Now innovation centers, business incubators, technology parks, innovation-industrial complexes, technology transfer centers, etc. are operating with varying degrees of efficiency throughout the country.

It should be noted such objects of innovation infrastructure as Sumgait Chemical Technology park (specialization - production of petrochemicals and other priority industries), Garadakh Technology park (ship building), Pirallakhi Technology park (pharmaceutical industry), Balakhani Technology park (recycling), Mingachevir Technology park (light industry).

Technology park at Baku Engineering University provides developers and innovative small enterprises with consulting services and practical advice on technology commercialization, project promotion, organizing contacts between investors and innovation developers, working with technology transfer networks, organizing effective communications with foreign partners, etc.) (Aras O.N., et al., 2016). Neftchala Technological Park organizes the production of construction materials, the production and repair of machines and mechanisms, the production of food and light industry products. Masalli Technological Park specializes in the production of furniture.

A network of Technology Transfer Centers (CTT) is developing in the republic. They are functioning in Baku Engineering University, State Academy of Oil and Industry, Azerbaijan Technological University, National Academy of Science.

The main activities of the Technology Transfer Centers are:

1. advertising, marketing, informational support, as well as PR of innovative projects; 
2. search and analysis of innovative projects commissioned by investors, search for potential investors for their implementation, support of selected projects;

3. examination and evaluation of innovative developments and proposals, also the preparation of particular documentation for grant applications;

4. legal protection (registration of trademarks, patents, etc.), legal and consulting services.

Among the institutions of the innovation process in Azerbaijan, the institutional framework for the transfer of innovative technologies and products remains weak. The demand for new innovative technologies in the republic seriously exceeds its supply and is growing at a faster rate (Hasanova P.A., 2009).

However, the demand for innovative products is always the main incentive for innovation. In addition, in a sector view the level of technology is very different.

In our opinion, Azerbaijan in the future can achieve its market share in high-tech goods, agricultural products and intellectual services in 5-10 positions: software, military equipment, space services, educational services, recreational services and tourism, food industry, pharmaceutics.

At the same time, the republic has the potential to improve its positions in fundamental and applied scientific research and the technologies they cause (Huseynova Arzu, 2013).

Thus, the main problem of the further institutional development for the transfer of innovations in the republic is the insufficient infrastructure development for the implementation and dissemination of new products (for Azerbaijan as a whole the number of sales infrastructure elements is small). In addition, there is a significant excess of demand over supply, as well as a significant differentiation of supply in the regional context.

Financing the innovation activities

As for the financial component of the infrastructure support of innovation, it should be noted that The Science Development Foundation operates under the President of Azerbaijan since 2009. The Foundation finances not only fundamental scientific works, but also applied and innovative projects.

Table 3. Succesful projects of the Science Competitions held by the Science Development Foundation by institutions in 2010-2015

\begin{tabular}{|l|l|l|l} 
The name of the organization & Number of & Number of & Total financing of projects
\end{tabular}




\begin{tabular}{|l|c|c|c|}
\hline & projects & projects $(\%)$ & (thousands manat) \\
\hline National Academy of Science & 272 & 61.26 & $26,620.8$ \\
\hline Educational institutions & 129 & 29.05 & $6,706.4$ \\
\hline $\begin{array}{l}\text { Field research institutes and } \\
\text { other government agencies }\end{array}$ & 32 & 7.21 & $2,061.5$ \\
\hline $\begin{array}{l}\text { Non-governmental } \\
\text { organizations, other } \\
\text { organizations and individiums }\end{array}$ & 11 & 2.48 & 369.5 \\
\hline Total & 444 & 100 & $35,758.2$ \\
\hline
\end{tabular}

Source: http://www.sdf.gov.az/development/uploads/neticeler_ve_statistika_en/1_muxtelif_ qurumlar_uzre_en.pdf

Another financial component of the infrastructure support of innovation is the State Fund for the Development of Information Technologies under the Ministry of Communications and High Technologies created in 2012. The main goal of the Fund is to support innovative entrepreneurship, to stimulate innovative projects, intellectual business, financial support for small innovative firms, to attract investors from abroad to IT and high technology.

By 2016 Fund allocated a total of 8.52 million manat of preferential loans to 13 business entities. Due to this, ICT infrastructure was developed, the sectors of import-substituting products were supported and new sectors of innovative services were created.

At present, to stimulate youth interest in innovation business incubators have been established in Azerbaijan State Economic University, Azerbaijan State University of Oil and Industry, Azerbaijan Technical University, Azerbaijan Architectural and Construction University, Azerbaijan Technology University in Ganja.

The Azerbaijan Export and Investment Support Fund (AZPROMO) has developed a wide range of activities to attract domestic and foreign investment in the development of non-oil sector of the economy with an innovative focus.

At present, the level of involvement of private capital in the innovations business remains insignificant in Azerbaijan compared to countries with a high level of innovative economy. Moreover, both the total amount of financing of innovative projects and the share of private capital in it remains low (EU - 85-90\%; USA - 90\%).

\section{CONCLUSION}

Our analysis of the institutional environment of the innovation economy in Azerbaijan allows us to conclude that its basic elements are currently being formed. However, the development of these elements is uneven and contradictory. There are certain pressing issues that require a comprehensive and operational solution.

The article substantiates a set of scientific and practical recommendations for improving innovation policy in Azerbaijan, according to certain areas (economic conditions, NIS organizational structure, regulatory framework, social prerequisites, international aspects of the state innovation policy), which include: the task of interlinking the goals of innovative 


\section{AJIT-e: Online Academic Journal of Information Technology \\ December 2018 - Special Issue/Aralık 2018 Özel Sayısı -Cilt/Vol: 9-Sayı/Num: 35 \\ DOI: 10.5824/1309-1581.2018.5.001.x}

development of the republic with the issues of competitiveness, creating conditions for interaction of the institutional structures of the Azerbaijani NIS with their modern forms, financial and administrative assistance in the development of high technologies.

The main directions and measures to improve the state innovation policy at the present stage are: 1) the development of the institutional environment of the innovation economy, which is urged to form the necessary institutions of the Azerbaijan innovation system (tax incentives for applied and corporate research and cooperation of science and business; scientific consulting for small and medium entrepreneurship by scientific organizations; the development of the marketing infrastructure - innovation technologies exchange; a unified educational complex "school - secondary vocational educational institutions - higher educational institutions - advanced training"; monitoring of domestic and foreign innovative development on the basis of the state statistics service; electronic system of innovation legislation and interactive system of legal support, etc.); 2) development and support of SMEs and their innovative activity (diversification of SMEs, a system of legislative, financial and tax measures to support it; development of venture investment in the field of SMEs; organization of effective interaction of all infrastructure elements providing SMEs; encouraging large enterprises to cooperate with SMEs in innovation sphere); 3) monitoring the effectiveness of innovation development, designed to identify weak elements of the country innovation system in order to take corrective measures in the framework of the state innovation policy; 4) reform of administrative institutions that ensure the implementation of state innovation policy.

Realization of these directions will help in resolving problems and contradictions towards creating an effective innovative economy of Azerbaijan with the market fundamentals of economic management combined with state participation and will finally form the main actors, mechanisms for their functioning and interaction, as well as all other necessary infrastructure institutes of the innovation system of the republic.

\section{REFERENCES}

Aleksandrin Yu.N. Adaptation of small business development institutions to an innovative economy. (Александрин Ю.Н. Адаптация институтов развития малого предпринимательства к инновационной экономике). Экономика: теория и практика. 2011. № 2 (22). С. 39-48

Alguliev R., Aliyev A. Main directions of academic and innovation activities in the development of the ICT sector in Azerbaijan. (Алгулиев Р., Алиев А. Основные направления академической и инновационной деятельности в развитии сферы ИКТ в Азербайджане). Экономист, №5, 2013, с.30-34

ANAS News. Science and Innovation. (AMEA-nın xəbərləri. Elm və innovasiya), 2011, AMEA Elmi innovasiyalar mərkəzi. Bakı, "Elm", 2011.

Aras O.N., Suleymanov E. Economics of Azerbaijan. (Aras O.N., Süleymanov E. Azərbaycan İqtisadiyyatı). "Şərq-Qərb" mətbəəsi, Bakı. 2016, 316 s.

Azerbaijan - 2020 Development Concept. ("Azərbaycan-2020: gələcəyə baxış” İnkişaf Konsepsiyas1), Bak1, 2012, 40 s. Retrieved from https://president.az/files/future_en.pdf 
Blyakhman L.S., Zyabrikov V.V. Innovative economy as a base for sustainable development of the CIS countries. (Бляхман А.С., Зябриков В.В. Инновационная экономика как база устойчивого развития стран СНГ). Проблемы современной экономики. 2011. № 3 (27). Retrieved from http://www.m-economy.ru/author.php?nAuthorId=57

Entrepreneurship in Azerbaijan. Azərbaycanda sahibkarlıq. Azərbaycan Respublikası İqtisadi İnkişaf Nazirliyi, Bakı: 2004, 150 s.

Eroshin A. The mechanism of state support of innovation: foreign experience. (Ерошин А. Механизм государственной поддержки инноваций: зарубежный опыт). МЭиМО. 2011. № 10. C. 21-29.

Hasanova P.A. The problems of innovation activity in Azerbaijan industry sector. (Həsənova P.Ә. Azərbaycan sənayesində innovasiya fəaliyyəti məsələləri). AMEA xəbərləri. Elm və innovasiya seriyası. 2009, №1, s.71-76

Huseynova Arzu. Analysis of monitoring results of the scientific organizations of Azerbaijan. Ukrainian Journal Ekonomist, Yuriy Kovalenko, issue 5, pages 62-65, May 2013.

Ivanova N. National Innovation Systems. (Иванова Н. Национальные инновационные системы). Вопросы экономики. №7, 2011. С. 61.

Karova E.A. Problems of institutionalization of the process of an innovative economy formation in Russia. (Карова Е.А. Проблемы институционализации процесса становления инновационной экономики в России). Вопросы экономики и права. 2010. № 12. С. 169-172.

Kihlgren A. Small business in Russia - Factors that slowed its development: An analysis. Communist Studies. Los Angeles, 2003. Vol.36. №2.

Lenchuk E.B, Vlaskin G.A. Investment aspects of innovation growth: global experience and Russian perspectives: monograph. (Денчук Е.Б., Власкин Г.А. Инвестиционные аспекты инновационного роста: мировой опыт и российские перспективы: монография). М.: Книжный дом «АИБРИКОМ», 2012, 288 с.

Lengrand L. Innovation policy and the regulatory framework: Making innovation an integral part of the broader structural agenda. Innovation/SMEs programme. Innovation papers № 28, 2008.

Shepelev G.V. Problems of innovation infrastructure development. (Шепелев Г.В. Проблемы развития инновационной инфраструктуры ). Наука и инновации. Retrieved from http://regions.extech.ru/left_menu/shepelev.php

Sklyarova E.E. Conceptual model of innovative economy. (Склярова Е.Е. Концептуальная модель инновационной экономики). Социально-экономические явления и процессы. 2012, № 9 (043) Retrieved from http://cyberleninka.ru/article/n/ kontseptualnaya-model-innovatsionnoy-ekonomiki 